\title{
Cadaver as an experimental a model for the study of midline incisional hernia ${ }^{1}$
}

\author{
Cadáver como modelo experimental para estudo da hérnia incisional mediana
}

\author{
Romar Ângelo Barbato Silveira', Fábio Xerfan Nahas", Bernardo Hochman ${ }^{\mathrm{III}}$, Felix Carlos Ocariz Bazzano ${ }^{\mathrm{IV}}$, Carlos Roberto \\ Amorimv, Lydia Masako Ferreira ${ }^{\mathrm{VI}}$ \\ ${ }^{1}$ Research performed at Postgraduate Program of Plastic Surgery, Integration (MINTER) between the Federal University of Sao Paulo (UNIFESP) and \\ the University of the Valley of the Sapucaí (UNIVAS), Brazil.

\footnotetext{
${ }^{\mathrm{I}}$ Master, Department of Surgery, Postgraduate Program of Plastic Surgery, UNIFESP, Sao Paulo, Brazil. Main author and responsible for manuscript preparation.

II PhD, Associate Professor, Division of Plastic Surgery, UNIFESP, Sao Paulo, Brazil. Responsible for conception and design of the study, manuscript writing, and critical revision.

III PhD, Affiliate Professor, Division of Plastic Surgery, UNIFESP, Sao Paulo, Brazil. Supervised all phases of the study.

${ }^{\text {IV }} \mathrm{PhD}$, Associate Professor, Bioethical Postgraduate Program, UNIVAS, Brazil. Planning and reviewer of the manuscript writing.

${ }^{v}$ Master, Department of Surgery, Postgraduate Program of Plastic Surgery, UNIFESP, Sao Paulo, Brazil. Helped with technical procedures, collection and processing of study informations.

${ }^{V 1} \mathrm{PhD}$, Full Professor, Head of Plastic Surgery Division and Chairwoman of Department of Surgery, UNIFESP, Sao Paulo, Brazil. Analysis and interpretation of data and critical revision.
}

\begin{abstract}
Purpose: To describe a cadaver model and to compare different techniques to correct midline incisional hernia using the tension at the musculoaponeurotic layer as a parameter. Methods: Twenty-four male cadavers were used to characterize the model. The tensile force applied to the anterior layers of the rectus abdominis muscle was measured after the linea alba was resected to create an abdominal wall defect. A dynamometer was used to measure the tensile force necessary to cause a 10-mm displacement of the tissues towards the midline. An index that allows comparison of tensile forces from different points was calculated by dividing the tensile force by the distance between the point of force application at the aponeurosis and the midline. Results: Cadaver is a good model for the study of midline incisional hernia. Conclusion: Cadaver can be used effectively as a model to evaluate tension of the abdominal wall when tissue advancement and musculoaponeurotic flaps are performed in the repair of midline incisional hernia.
\end{abstract}

Key words: Hernia, Ventral. Abdominal Muscles. Tensile Strength. Rectus Abdominis. Cadaver.

\section{RESUMO}

Objetivo: Este estudo descreve o cadáver como modelo experimental para comparar diferentes técnicas para correção da hérnia incisional mediana usando como parâmetro a tensão músculo-aponeurotica. Métodos: Vinte e quatro cadáveres adultos masculinos foram usados para caracterizar este modelo. A força de tensão aplicada na lamina anterior do músculo reto do abdome foi medida após ressecção da linha alba criando um defeito abdominal. Um dinamômetro foi utilizado para medir a força de tensão necessária para ocasionar o deslocamento de 10-mm do tecido até a linha mediana. Um índice para comparar as forças de tensão em diferentes pontos foi calculado dividindo a força de tensão pela distancia entre o ponto de aplicação da força na aponeurose e a linha mediana. Resultados: O cadáver é um bom modelo para estudo da hérnia incisional mediana. Conclusão: O cadáver pode ser utilizado efetivamente como um modelo para avaliação da tensão da parede abdominal quando o avanço de tecidos e retalhos músculo-aponeuroticos são utilizados no reparo de uma hérnia incisional mediana.

Descritores: Hérnia Ventral. Músculos Abdominais. Resistência à Tração. Reto do Abdome. Cadaver. 


\section{Introduction}

Suture of the abdominal after laparotomies wall is one of the most common procedures in surgical practice ${ }^{1,2}$. The closure of the abdominal wall serves to restore preoperative functions ${ }^{3}$. The procedure should be technically simple, have a low rate of complications such as wound dehiscence, incisional hernia, or fistula formation, and prevent formation of unaesthetic scars ${ }^{4}$.

Abdominal wound dehiscence is defined as the separation of the musculoaponeurotic layers and consequent formation of incisional hernia ${ }^{5}$. One of the major causes of recurrence after repair of defects is excessive tension on the suture line $e^{6,7}$, which may lead to ischemia of the musculoaponeurotic layers followed by dehiscence ${ }^{8}$. Recently, several techniques have been developed for the treatment of incisional hernia using local tissues ${ }^{9-12}$. However, there is no specific model for the study of midline incisional hernia in the literature. Therefore, the aim of the present study was to describe a cadaver model for the study of techniques for repair of midline incisional hernia.

\section{Methods}

The study was approved by the Research Ethics Committee of the University of the Valley of the Sapucaí (UNIVAS), Brazil. Twenty-four male cadavers obtained from the Legal Medicine Unit of the 13th Regional Civil Police Station in Minas Gerais, Brazil, were used to characterize the model. This anatomical study was based on the experimental model for the study of abdominal wall tension described by Nahas and Ferreira ${ }^{13}$. In contrast to that model, in the present study, a defect was created in the abdominal wall, allowing a detailed examination of how the procedure affects the patient.

Initially, the cadaver was placed in the supine position. A xiphoid-to-pubis incision was made through the skin and superficial fascia until the linea alba was exposed, and continued around both sides of the umbilicus. Next, a standardized supraaponeurotic dissection was made; it was limited superiorly by the lower costal arch, inferiorly by the inguinal arch, and bilaterally by the linea semilunaris. The linea alba was resected along the edges in contact with the rectus abdominis muscle (Figure 1).

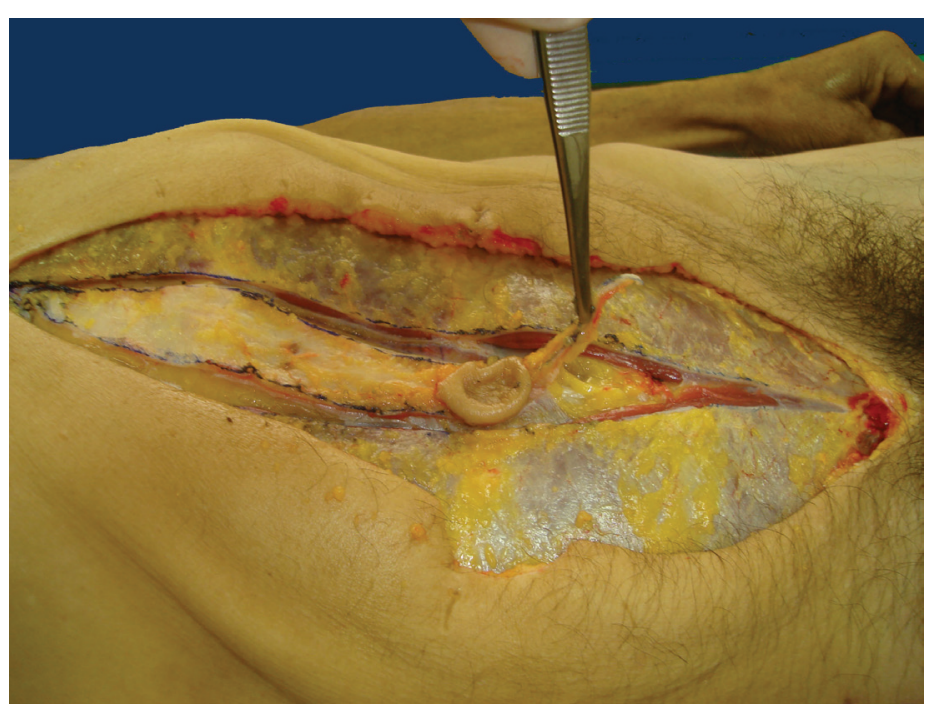

FIGURE 1 - Creation of the musculoaponeurotic defect in the cadaver.

Study points were marked on the anterior layer of the rectus abdominis muscle at the desired measurement locations, without muscle or aponeurosis displacement. Reference points for tensile measurements were marked on the anterior aponeurosis. In order to demonstrate the scope of the model, reference points were placed in the supraumbilical region at 3,6 and $9 \mathrm{~cm}$ above the upper edge of the umbilicus, and in the infraumbilical region at $2,4,6$, and $8 \mathrm{~cm}$ below the lower edge of the umbilicus. Similarly, reference points were marked on the posterior aponeurosis; they were placed in the supraumbilical region at 3,6 and $9 \mathrm{~cm}$ above the upper edge of the umbilicus, and in the infraumbilical region at 2 and $4 \mathrm{~cm}$ below the lower edge of the umbilicus.

A cross stitch was placed at all 14 study points to serve as a traction loop. The traction loop was made of 2-0 nylon monofilament thread on a needle, and its diameter was standardized to $10-\mathrm{mm}$ by placing a $10-\mathrm{mm}$ diameter clamp between the two ends of the thread to act as a stop, limiting further tightening of the knot. In order to create the traction loop, the needle must only penetrate the aponeurotic layer, avoiding the underlying muscle tissue. The traction loops were made $10 \mathrm{~mm}$ lateral to the resection edge of the linea alba (Figure 2). 


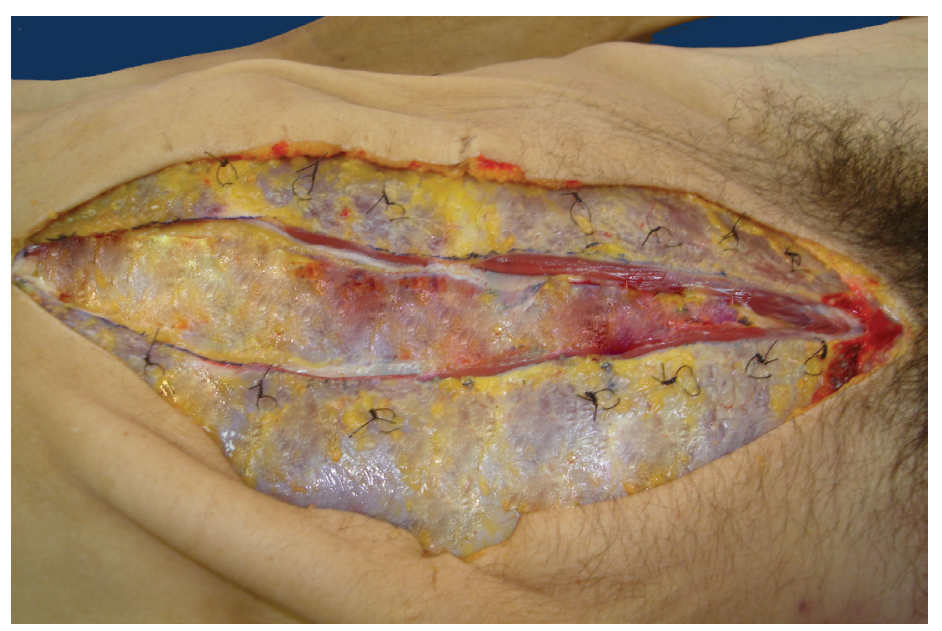

FIGURE 2 - Traction loops on the anterior layer of the rectus abdominis muscle.

The hook of a mechanical dynamometer $\left(\mathrm{Crown}^{\circledR} \mathrm{BR}\right.$ dynamometer, Sao Paulo, Brazil) with capacity of 3000 gf was inserted into the traction loop. Next, a tensile force was applied in the medial direction to the anterior layer of the rectus abdominis muscle sheath to cause a $10-\mathrm{mm}$ displacement. The tissue displacement was measured using an analog caliper and the tensile force necessary to cause the displacement was measured with the dynamometer. The dynamometer was held perpendicular to the midline (Figure 3) and the tensile force was applied tangentially to the aponeurosis. Repeated measurements of tensile force were made by two independent observers. If there were differences between observers regarding readings, the average measurement of the two observers was used.

Dynamometer readings of tensile force were inserted into the following equation for the calculation of the traction index described by Nahas and Ferreira ${ }^{13-15}$ :

$$
\mathrm{TI}=\underline{\mathrm{F}},
$$

where $T I$ is the traction index $(\mathrm{kgf} / \mathrm{cm}) ; F$ is the tensile force $(\mathrm{kgf})$ at the study point; and $d$ is the displacement distance $(\mathrm{cm})$. The traction index was calculated for a constant displacement distance of $1 \mathrm{~cm}(10 \mathrm{~mm})$.

Traction index values calculated using the equation above will be used for the comparison of tensile forces from different points and between the anterior and posterior layers of the rectus sheath.

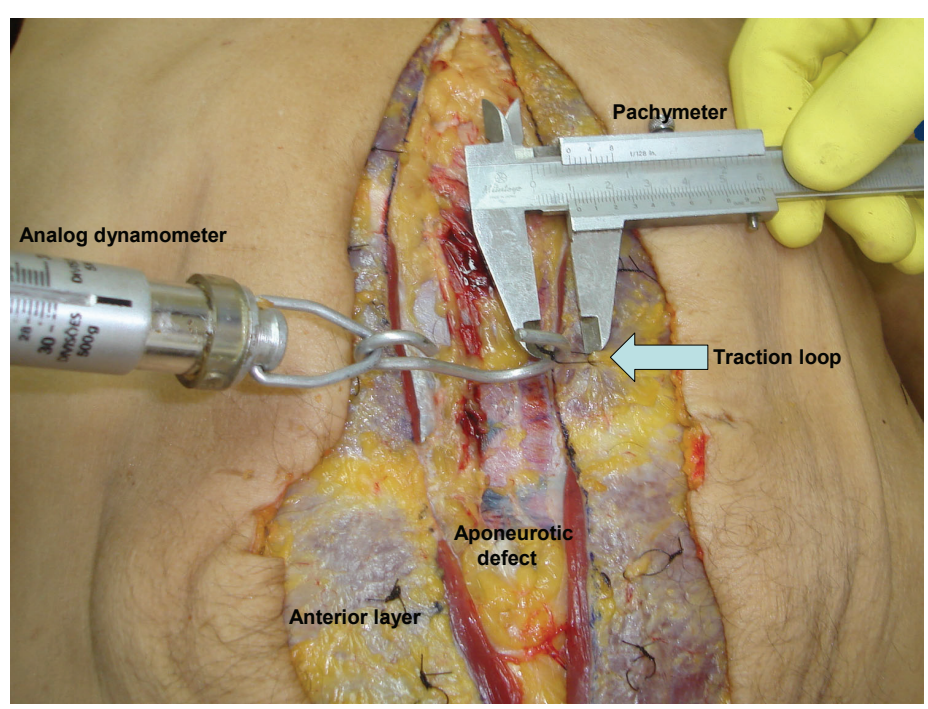

FIGURE 3 - Measurement of the tensile force.

\section{Results}

The cadaver model of midline incisional hernia was feasible and provided accurate and reproducible results.

\section{Discussion}

The cadaver can be used effectively as a model of midline incisional hernia. This model allows the evaluation of techniques for reducing aponeurotic tension by using local tissues techniques that use aponeurotic incision and undermining or local musculoaponeurotic flaps in the repair of midline incisional hernia can be evaluated using this model.

\section{References}

1. Tognini JRF, Goldenberg S. Síntese da parede abdominal: sutura continua ou com pontos separados? Revisão de literatura. Acta Cir Bras. 1998;13(2):23-9.

2. Burger JW, Van't Riet M, Jeekel J. Abdominal incisions: techniques and postoperative complications. Scand J Surg. 2002;91(4):315-21.

3. Wadstrom J, Gerdim B. Closure of the abdominal wall; how and why. Acta Chir Scand. 1990;156:75-82.

4. Bucknall TE, Ellis H. Abdominal Wound closure: a comparison of monofilament nylon and polyglycolic acid. Surgery. 1981;89:672-7.

5. Leaper DJ, Allan A, May RE, Corfield AP Kennedy RH. Abdominal wound closure: a trial of nylon, polyglycolic acid and steel sutures. Br J Surg. 1977;64:603-6.

6. Cohen M, Morales R, Fildes J, Barrett J. Staged reconstruction after gunshot wounds to the abdomen. Plast Reconstr Surg. 2001;108:8392.

7. Höer J, Klinge U, Anurov M, Titkova S, Oettinger A, Schumpelick V. Tension banding closure of laparotomies: results of an experimental study in dogs. Langenbecks Arch Surg. 2002;307:309-14.

8. Mäkelä JT, Kiviniemi H, Juvonen T, Laitinen S. Factors influencing wound dehiscence after midline laparotomy. Am J Surg. 
1995; 170:387-90.

9. Nahas FX, Ishida J, Gemperli R, Ferreira MC. Abdominal wall closure after selective aponeurotic incision and undermining. Ann Plast Surg. 1998;41(6):606-13.

10. Barbosa MV, Nahas FX, Oliveira Filho RS, Ayaviri NAM, Novo NF, Ferreira LM. A variation in the component separation techinique that preserves linea semilunaris: a study in cadavers and a clinical case. J Plast Reconstr Aesthet Surg. 2010r;63(3):524-31.

11. Lazaro da Silva A. Surgical corretion of longitudinal mediano or paramedian incisional hérnia. Surg Gynecol Obstet. 1979;148:57983.

12. Ramirez OM, Ruas E, Dellon L.”Components Separation" method for closure of abdominal wall defects: na anatomic and clinical study. Plast Recosntr Surg. 1990;86:519-26.
13. Nahas FX, Ferreira LM. Cadáver as an model to study abdominal wall tension. Acta Cir Bras. 2003;18(special suppl.):37-45.

14. Amorim CR, Nahas FX, Souza VC, Ely PB, Silveira RAB, Novo NF, Ferreira LM. Tensile strength of the posterior and anterior layer of the rectus abdominis muscle sheath in cadavers. Acta Cir Bras. 2007; 2(4):254-8.

15. Silveira RAB, Nahas FX, Hochman B, Bazzano FCO, Amorim CR, Juliano Y, Passos VM, Ferreira LM. Mapping traction strength of anterior rectus sheath. A study in cadaver. Acta Cir Bras. 2010;25(4):347-9.

\section{Correspondence:}

Prof. Dr. Fabio Xerfan Nahas

Disciplina Cirurgia Plástica, UNIFESP

Rua Napoleão de Barros, $715 / 4^{\circ}$ andar

04024-0022 São Paulo - SP Brasil

Tel: (55 11)5576-4065/5576-4118

fabionahas@uol.com.br
Conflict of interest: none Financial source: none

Received: December 10, 2010

Review: February 14, 2011

Accepted: March 15, 2011 